\title{
Sciendo
}

PROCEEDINGS OF THE LATVIAN ACADEMY OF SCIENCES. Section B, Vol. 74 (2020), No. 3 (726), pp. 215-221.

DOI: $\quad 10.2478$ /prolas-2020-0033

\section{QTL-GENES IN BREEDS AND HYBRIDS OF UKRAINIAN SHEEP}

\author{
Vasyl' lovenko ${ }^{1, \#}$, Yurii Vdjvichenko ${ }^{1}$, Igor Gorbatenko ${ }^{2,3}$, Kostantyn Skrepets ${ }^{1}$, \\ Ilona Hladii ${ }^{1}$, Pavlo Zharuk ${ }^{1}$, and Nadiya Pisarenco ${ }^{1}$ \\ 1 "Ascania Nova" Institute of Animal Breeding in the Steppe Regions named after M. F. Ivanov - National Scientific Selection-Genetics \\ Center for Sheep Breeding, 1 Soborna Str., Askania Nova, Chaplynka district, Kherson region, 75230, UKRAINE \\ 2 Mykolaiv Agrarian National University, 9 Georgiya Gongadze Str., Mykolaiv, 54029, UKRAINE \\ 3 "Southern State Agricultural Research Station" Institute of Water Problems and Melioration of the National Academy of Agrarian \\ Sciences of Ukraine, 71 Chornomorska Str., Hola Prystan, Kherson region, 75600, UKRAINE \\ \# Corresponding autor, v.n.iovenko49@gmail.com
}

Communicated by Isaak Rashal

\begin{abstract}
For the first time, the genetic structure of sheep breeds (Ascanian Fine-Fleeced, Ascanian Meat-and-Wool, AND Ascanian Karakul) and the hybrid Ascanian Fine-Fleeced $\times$ Texel was studied for structural gene variants: growth hormone, calpastatin, myostatin, and Booroola bone morphogenetic protein. In all studied groups, sheep were characterised by polymorphism of two loci, growth hormone and calpastatin. Two genotypes $(A / A, A / B)$ represent genes of growth hormone structure, and three $(M / M, M / N, N / N)$ represent genes of calpastatin structure. Other genes are in a monomorphic state. Analysis of the genetic relationships between the studied gene pools showed that there was a definite relationship between productivity of sheep herds and their molecular genetic parameters. Thus, the frequencies of individual genotypes and alleles change in the direction from Fine-Fleeced animals to sheep bred for meat productivity. For example, the heterozygous genotype $A / B$ proportion of growth hormone gene increases in this direction from $0 \%$ to $38.2 \%$, and allele $A$ from 0.083 to 0.191 . The live weight of Fine-Fleeced lambs with genotype $A / B$ at birth was $4.5 \mathrm{~kg}$, and with homozygous genotype $A / A-4.9 \mathrm{~kg}(\mathrm{p}<0.001)$. This difference is genetically related to the meat productivity of sheep. A similar relationship was established for young Ascanian Karakul sheep. According to the distribution of polymorphic loci variants, the gene pools of Ascanian Meat-and-Wool breed and cross-bred animals are most similar closest among themselves, which is explained by the same direction of their productivity. At the same time, all populations are in genetic equilibrium according to Hardy-Weinberg equations, which indicates a high level of their consolidation. Sheep, which have the A/A homozygote of the gene growth hormone, have increased body weight.
\end{abstract}

Key words: Ovis, gene pool, DNA-marker, polymorphism, structure.

\section{INTRODUCTION}

In the modern history of farm animal breeding, breeders at the Askania Nova Livestock Institute have achieved impressive results, especially in the sheep farming industry. They created highly productive gene pools of sheep in various directions of productivity, which were not inferior in terms of the development of productive traits to the best world analogues. These include Ascanian Fine-Fleeced, Ascanian Meat-and-Wool with crossbred wool, and the Ascanian Karakul breed. However, despite all the success, at the present stage of the development of sheep breeding, the usage of classical breeding methods alone, based on the use of phe- notype assessment methods, largely impedes the efficiency of breeding. The ability to work directly with hereditary material becomes more and more relevant and the widespread usage of marker-associated selection (MAS) in our country is only a matter of time. In this regard, the purpose of our work was to search for scientific and practical approaches to increase the efficiency of sheep breeding with purebred breeding and crossbreeding.

Studying the genetic structure of domestic sheep gene pools is a necessary first step in the overall MAS strategy. Conducting genetic-population studies allows to evaluate the allelic diversity of breeds for each of the target loci, and to 
identify polymorphic and monomorphic variants of various genes. It is also important to determine the presence/absence of deviations from the state of genetic equilibrium of the population according to Hardy-Weinberg equations, which allows to assess whether selection or other factors is affecting the dynamics of the structure of the population, i.e. determine the direction of the breeding process as a whole.

The next step is to study the relationship of different allelic variants of QTL genes with quantitative traits of different breeds of sheep and productivity directions. In this context, the potential breed specificity of each of the promising markers is of great importance, as it is associated with variability in the effect of a particular allele on a particular trait in different sheep gene pools.

The paper presents the results of a study of the genetic structure of a series of QTL genes of Ukrainian sheep breeds that differ in productivity. Candidate genes were selected to study polymorphisms directly related to physiological functions of the sheep, i.e. development of the main quantitative traits. These genes examined are associated with growth hormone, calpastatin, myostatin, Booroola, and bone morphogenetic protein.

The growth hormone gene belongs to one of the most popular objects in animal genetics. In different species of vertebrates, it has similar structure; in particular, the amino acid sequence of growth hormone in cattle and sheep has a homology of $98.7 \%$ (Wallis et al., 1998). In sheep, it is mapped on chromosome 11 and contains five exons and four introns (Ofir, 1997). This gene can accelerate metabolism and stimulate the growth of many organs and tissues, especially bones, muscles and internal organs, and has a direct effect on the synthesis and secretion of the hormone and plays an important role in the growth of animals (Mokhtar et al., 2009). In most of the studied breeds, it is in a polymorphic state with two allelic variants (Ahlawat et al., 2014).

The tenderness of meat is one of the important indicators in assessing the quality of meat. One of the factors influencing the meat tendering process after slaughter is the calpaincalpastatin system (CCS). Calpastatin affects the proteolysis of myofibrils due to the regulation of calpain, which can initiate the degradation of myofibril proteins (titin and nebulin) after slaughter (Koohmaraie et al., 1995). The polymorphism of this gene is due to the presence of three genotypes and two alleles and is characteristic for many breeds of different productivity (Shahroudi et al., 2006, SzkudlarekKowalczyk et al., 2011).

The myostatin gene (myostatin, MSTN) is also known as growth factor and differentiation factor $8-G D F-8$ (growth differentiation factor-8) - one of the most studied candidate genes for meat productivity of farm animals. Mutations of the myostatin gene (GenelD: 443449) are associated with an increase in skeletal muscle mass, and individuals carrying this mutation are distinguished by the phe- notype of the so-called "double musculature" (Kambadur et al., 1997). Study of the structure of this sheep gene showed that it is located on the $2^{\text {nd }}$ chromosome and consists of three exons and two introns.

Most studies on the polymorphism of the MSTN gene and its potential use in breeding and selection of sheep have focused on a mutation localized in the $3^{\text {rd }}$ exon of this gene. The PCR-RFLP method allowed to identify two alleles $\mathrm{m}$ (which is visualised with three fragments of 131, 123 and 83 bp length) and $M$ (which contains a mutation that leads to the appearance of a hypermuscular effect, and visualised with four fragments 337, 131123 and 83 bp) (Elkorshy et al., 2013; Jamshidi et al., 2014). Sheep homozygous for this mutation have up to 10 per cent more muscle mass and 10 per cent less fat in the carcass.

The Booroola gene $(F e c B)$ belongs to the superfamily of transforming growth factor $\beta$ (TGF $\beta$ ) (Davis et al., 2002). It is localised on the sixth chromosome and has an additive effect on the number of ovulating ovules in each ovulatory cycle. In sheep with this mutation, 4-12 ovules mature immediately, which further contributes to the birth of 4-10 lambs (Montgomeri et al., 1993; Mokhtar et al., 2009; Shamik et al., 2009). In studied sheep breeds this gene is generally monomorphic (El-Hanafi et al., 2009).

The BMP15 gene is located on the $\mathrm{X}$ chromosome and it regulates the development of oocytes and follicles. Animals heterozygous for the BMP15 mutation have a higher average number of ovulating egg-cells than animals with a wild-type genotype. In contrast, ewes homozygous for BMP15 mutation are infertile due to impaired normal follicular development in the early stages of formation (Galloway et al., 2000; Ibeagha-Awenu et al., 2008). In most of the studied gene pools of sheep from different regions of the planet, this gene is also monomorphic (Palmer et al., 1997).

The aim of our study was to examine the polymorphism features of individual genes in relation to quantitative traits of sheep bred in Ukraine.

\section{MATERIALS AND METHODS}

The study was carried out on Ascanian Meat-and-Wool sheep (AMWS), Ascanian Karakul (AKS), Ascanian FineFleeced (AFS) of breeds and cross-breeds Ascanian FineFleeced Texel $($ AFS $\times$ T), which were bred in the Ascania Nova breeding farm of the Kherson region.

The PCR-RFLP method was used to study polymorphism of the following genes: genes for meat productivity — growth hormone $(G H)$, calpastatin $(C A S T)$ and myostatin $(M S T N)$; multi-fertility - Booroola $(\mathrm{FecB})$ and bone morphogenetic protein 15 (BMP15). These genes were chosen because they control important economically useful traits of sheep. DNA was isolated from the experimental samples by a standard method using the "DNA sorb-B reagent kit" (Ampli Sens). Amplification was carried out using the programmable ther- 
Table 1. Primers used for amplification of different genes

\begin{tabular}{l|lc}
\hline Locus & \multicolumn{1}{|c}{ Sequence (5' - 3') } & Product \\
\hline \multirow{2}{*}{ FH } & F: 5'-CTCTGCCTGCCCTGGACT-3' & $422 \mathrm{bp}$ \\
& R: 5'-GGAGAAGCAGAAGGCAAC-3' & \\
CAST & F: 5'-TGGGGCCCAATGACGCCATCGATG-3'; & $622 \mathrm{bp}$ \\
& R: 5'-GGTGGAGCAGCACTTCTGATCACC-3' & \\
\multirow{2}{*}{ STN } & F 5'- CCG GAG AGA CTT TGG GCT TGA -3' & $337 \mathrm{bp}$ \\
& R5'-TCA TGA GCA CCC ACA GCG GTC -3' & \\
$F e c B$ & F: 5'-CCAGAGGACAATAGCAAAGCAAA-3' & $190 \mathrm{bp}$ \\
& R: 5'-CAAGATGTTTCATGCCTCATCAACACGGTC-3' \\
BMP15 & F: 5'-TTCTCCGTCTAGGGGTATGAG-3' & $356 \mathrm{bp}$ \\
& R: 5'-AGGGAACAAGAGCAAAGCGTTAGC-3' &
\end{tabular}

mal cycler Libe Line according to the programmes selected for each locus using the primers presented in Table 1 .

PCR was carried out according to the following temperature conditions for the $\mathrm{GH}$ gene fragment: one cycle - denaturation $94{ }^{\circ} \mathrm{C}$ for $5 \mathrm{~min}$; 35 cycles of denaturation $-95^{\circ} \mathrm{C}$ for $30 \mathrm{~s}$, annealing $-30 \mathrm{~s}$ at $65^{\circ} \mathrm{C}$ and elongation $-72{ }^{\circ} \mathrm{C}$ for $45 \mathrm{~s}$, one cycle - final elongation $72^{\circ} \mathrm{C} 7 \mathrm{~min}$; fragment of the CAST gene: one cycle - denaturation $94{ }^{\circ} \mathrm{C}$ for 5 min, 33 cycles of denaturation $-94{ }^{\circ} \mathrm{C}$ for $15 \mathrm{~s}$, annealing $-30 \mathrm{~s}$ at $67^{\circ} \mathrm{C}$ and elongation $-72{ }^{\circ} \mathrm{C}$ for $30 \mathrm{~s}$; one cycle - final elongation $72{ }^{\circ} \mathrm{C} 5 \mathrm{~min}$; MSTN gene fragment: one cycle — denaturation $95{ }^{\circ} \mathrm{C}$ for $5 \mathrm{~min}, 33$ cycles of denaturation $-95{ }^{\circ} \mathrm{C} 40 \mathrm{~s}$, annealing - $40 \mathrm{~s}$ at $67{ }^{\circ} \mathrm{C}$ and elongation $-72{ }^{\circ} \mathrm{C} 40 \mathrm{~s}$, one cycle - final elongation $72{ }^{\circ} \mathrm{C} 5 \mathrm{~min}$; fragment of the $\mathrm{FecB}$ gene: one cycle — denaturation $94{ }^{\circ} \mathrm{C}$ for $5 \mathrm{~min}$; 33 cycles of denaturation $-94^{\circ} \mathrm{C}$ for $15 \mathrm{~s}$, annealing $-30 \mathrm{~s}$ at $60^{\circ} \mathrm{C}$ and elongation $-72^{\circ} \mathrm{C}$ for $30 \mathrm{~s}$, one cycle - final elongation $72{ }^{\circ} \mathrm{C} 5 \mathrm{~min}$; BMP 15 gene fragment: one cycle - denaturation $94{ }^{\circ} \mathrm{C}$ for $5 \mathrm{~min}$, 33 cycles of denaturation $-94{ }^{\circ} \mathrm{C}$ for $15 \mathrm{~s}$, annealing -30 $\mathrm{s}$ at $62{ }^{\circ} \mathrm{C}$ and elongation $-72{ }^{\circ} \mathrm{C}$ for $30 \mathrm{~s}$, one cycle - final elongation $72{ }^{\circ} \mathrm{C} 5 \mathrm{~min}$.

Amplified fragments were treated with restriction endonucleases: restriction enzyme Hae III was used for the $G H$ gene (GG/CC), for CAST - MspI (C/CGG), for MSTN Hae III (GG/CC), for $F e c B-$ AvalI (G/GACC), and for BMP15 - Mph1103I (ATGCA/T), according to standard methods of the manufacturer ("Thermo Scientific", USA). The restriction products were separated by horizontal electrophoresis in a 2-3\% agarose gel at a voltage of $80 \mathrm{~V}$ for $30 \mathrm{~min}$. Visualisation was performed using ethidium bromide in the ultraviolet spectrum. The size of restriction fragments was determined using molecular weight markers (Gene Ruler TM 50 bp DNA Ladder "Fermetas" and pUC19/MspI "SibEnzyme").

Genotyping for each of the loci was carried out by analysis of the obtained electrophoregrams. When designating allelles and genotypes, materials from other researchers were used (El-Hanafi et al., 2009; Jamshidi et al., 2014; Kumari et al., 2014; Avanus, 2015; Shabir et al., 2019).

Based on the obtained data, the actual $(\mathrm{O})$ and theoretical (E) distribution of genotypes, the frequency of genotypes and alleles, and the correspondence to the genetic balance of the population according to Hardy-Weinberg equations were calculated by the $\chi^{2}$ method, actual $\left(\mathrm{H}_{\mathrm{O}}\right)$ and theoretical $\left(\mathrm{H}_{\mathrm{e}}\right)$ heterozygosity, effective number of alleles $\left(\mathrm{n}_{\mathrm{e}}\right)$, and Wright's fixation index (Fis) (Merkureva, 1997; Nei et al., 1983). GenAlEx 6.5 software was used in the calculations (Peakall et al., 2012).

\section{RESULTS}

Of the five QTL genes studied, the use of PCR and restriction analysis revealed various polymorphic variants of growth hormone and calpastatin genes in Ukrainian sheep populations (Fig. 1). In the studied populations, two - A/A and $\mathrm{A} / \mathrm{B}$ genotypes were identified for the growth hormone gene, from the three theoretically possible ones. There is no $\mathrm{B} / \mathrm{B}$ homozygote. The A/A genotype is represented by two fragments - 366 and 56 base pairs long (bp), and the A/B genotype by three fragments, 422, 366, and 56 bp long.

Significant differences occurred between gene pools in the proportion of identified genotypes (Table 2). In the Ascanian Fine-Fleeced breed, this gene was represented by only one genotype - homozygote A/A (100\%). In the rest, its proportion varied from $62.8 \%$ (AMWS) to $95.2 \%$ (AFS $\times \mathrm{T})$. Heterozygote $\mathrm{A} / \mathrm{B}$ was found in one individual $(4.8 \%)$ in the crossbreeds, in five $(16.7 \%)$ in AKS and in 13 individuals $(38.0 \%)$ in AMWS. Accordingly, the distribution of alleles of this locus was quite contrasting, with the absolute dominance of variant $G H^{A}$ from 0.809 to 0.976 .

The monomorphic state of the $G H$ locus in the Ukrainian population of Merino sheep of the Ukrainian selection caused a low level of polymorphism in the group of hybrid animals obtained from crossing AFS sheep and the Texel meat breed. The number of effective alleles in AMWS was 1.44, compared to 1.05 in the cross-breeding genotypes. Correspondingly, the degree of heterozygosity of populations at this locus was the highest in the crossbred sheep population (0.309), and the lowest in the crossbreeding group (0.047). The gene pool of Karakul sheep in these parameters occupies a middle position, $\mathrm{n}_{\mathrm{e}}=1.18$; Ho -0.152 . The Wright fixation index as a whole indicated a weakly

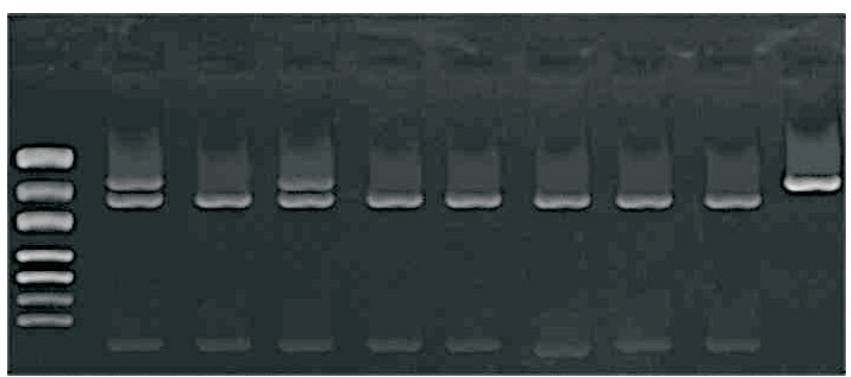

$\begin{array}{llllllllll}1 & 2 & 3 & 4 & 5 & 6 & 7 & 8 & 9 & 10\end{array}$

Fig 1. Electrophoregram of the separation of $G H$ gene restriction products (restrictase Hae III). 1, DNA-marker MspI (501,404,331,242. 190,147,111); 2, 4, genotype AB (422, 366, 56 bp.); 3, 5, 6, 7, 8, 9, genotype AA $(366,56 \mathrm{bp}$ ); 10, PCR product (422 bp.) 
Table 2. Genetic structure of various sheep populations gene pools at the GH locus

\begin{tabular}{|c|c|c|c|c|c|c|c|c|c|c|c|c|}
\hline \multirow{3}{*}{$\begin{array}{r}\text { Gene } \\
\text { pool }\end{array}$} & \multirow{3}{*}{$\mathrm{n}$} & \multicolumn{4}{|c|}{ Genotype, $\mathrm{n}$} & \multicolumn{2}{|c|}{ Allele } & \multirow{3}{*}{$\mathrm{n}_{\mathrm{e}}$} & \multirow{3}{*}{$\mathrm{H}_{\mathrm{E}}$} & \multirow{3}{*}{$\mathrm{H}_{\mathrm{O}}$} & \multirow{3}{*}{ Fis } & \multirow{3}{*}{$\chi^{2}$} \\
\hline & & \multicolumn{2}{|c|}{ AA } & \multicolumn{2}{|c|}{$\mathrm{AB}$} & \multirow[t]{2}{*}{ A } & \multirow[t]{2}{*}{ B } & & & & & \\
\hline & & $\mathrm{O}$ & $\mathrm{E}$ & $\mathrm{O}$ & $\mathrm{E}$ & & & & & & & \\
\hline $\mathrm{AKS}$ & 30 & 25.2 & 25 & 4.6 & 5 & 0.917 & 0.083 & 1.18 & 0.153 & 0.152 & -0.007 & 0.04 \\
\hline AFS & 41 & 41.0 & 41 & - & - & 1.0 & 0 & 0 & 0 & 0 & - & - \\
\hline $\mathrm{AFS} \times \mathrm{T}$ & 21 & 20.0 & 20 & 1.0 & 1 & 0.976 & 0.024 & 1.05 & 0.047 & 0.047 & 0 & 0 \\
\hline
\end{tabular}

expressed excess of heterozygotes for the studied genes. However, for the $G H$ locus, a certain excess of homozygous individuals was detected in the AMWS population (Fis = $-0.052)$.

Analysis of the actual and theoretical distribution of different genotypes revealed the absence of a disturbance in the genetic equilibrium in each of the studied populations. Fluctuations in the values of the Fis index were within the equilibrium state and indicated a low level of breeding pressure on the structure of sheep herds according to the indicated QTL gene.

A certain degree of polymorphism with the presence of three genotypes (M/M, M/N, N/N) was also established for the calpastatin gene in all studied populations, determined by two alleles, $C A S T^{M}$ and $C A S T^{N}$ (Fig. 2). The length of the chromosome region of this gene was $622 \mathrm{bp}$. After restriction (restriction enzyme Msp1) on the phoregram, carriers of homozygote M/M identified two bands with lengths of 336 and $286 \mathrm{bp}$. The heterozygote $\mathrm{M} / \mathrm{N}$ was represented by three fragments, 622,336 and 286 bp long, and the N/N

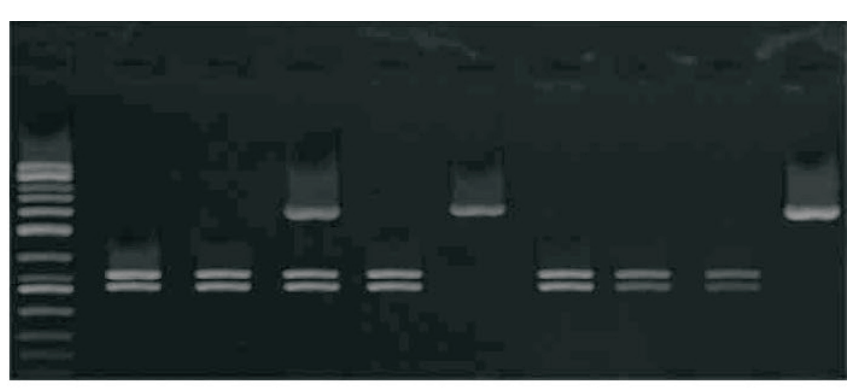

$\begin{array}{llllllllll}1 & 2 & 3 & 4 & 5 & 6 & 7 & 8 & 9 & 10\end{array}$

Fig. 2. Electrophoregram of the separation of CAST gene restriction products (restrictase MspI). 1, DNA-marker GeneRuler TM 50bp DNA Ladder "Fermetas"; 2, 3, 5, 7, 8, 9, genotype MM (336, 286 bp.); 4, genotype $\operatorname{MN}(622,336,286$ bp.); 6, genotypeNNB (622 bp.); 10, PCR product without restriction (622 bp.) homozygote was represented by one fragment with $622 \mathrm{bp}$ length.

Regarding the distribution of genotypes (Table 3), all three variants were identified only in the population of the Ascanian Karakul breed. In the remaining groups of sheep there was no N/N homozygote. Homozygote M/M had the highest proportion — $66.7 \%$ (AFS) to $90.9 \%$ (AMWS). Accordingly, the frequency of the $C A S T^{M}$ allele is at the level of $0.826-0.955$, and the $C A S T^{N}$ allele at the level of 0.045-0.174. Based on this, the degree of polymorphism of this locus in the populations of sheep of Ukrainian selection was relatively low and ranged from 1.09 (AMWS) to 1.40 (AKS). This indicates that the gene pools of the meat direction of productivity in comparison with the wool and astrakhan areas are distinguished by a small number of effective alleles.

When comparing the actual and theoretical heterozygosity, a complete coincidence of their values was found in all analysed groups of sheep. Hence, all the values of the Wright fixation index are equal to zero, which indicates a low level of artificial selection at this locus of the studied gene pools at this stage of breeding of flocks of sheep. Confirmation of this was shown by the $\chi^{2}$ value of only $0.0-0.48$, which showed that all populations were in a state of genetic equilibrium.

In general, the obtained values of population genetic parameters are close to those in growth hormone and are consistent with the characteristics of other gene pools of sheep of foreign origin (Shahroudi et al., 2006; SzkudlarekKowalczyk et al., 2011).

Based on the obtained data on the genetic structure of the four sheep populations, the genetic distance indices between them were calculated (Table 4).

Genetic distances showed that productive breed (Ascanian Meat-and-Wool breed and cross-breed sheep) were similar

Table 3. Genetic structure of various sheep populations gene pools at the CAST locus

\begin{tabular}{|c|c|c|c|c|c|c|c|c|c|c|c|c|c|c|}
\hline \multirow{3}{*}{$\begin{array}{r}\text { Gene } \\
\text { pool }\end{array}$} & \multirow{3}{*}{$\mathrm{n}$} & \multicolumn{6}{|c|}{ Genotype, n } & \multicolumn{2}{|c|}{ Allele } & \multirow{3}{*}{$\mathrm{n}_{\mathrm{e}}$} & \multirow{3}{*}{$\mathrm{H}_{\mathrm{E}}$} & \multirow{3}{*}{$\mathrm{H}_{\mathrm{O}}$} & \multirow{3}{*}{ Fis } & \multirow{3}{*}{$\chi^{2}$} \\
\hline & & \multicolumn{2}{|c|}{ MM } & \multicolumn{2}{|c|}{ MNB } & \multicolumn{2}{|c|}{$\mathrm{NN}$} & \multirow{2}{*}{ M } & \multirow[t]{2}{*}{$\mathrm{N}$} & & & & & \\
\hline & & $\mathrm{O}$ & $\mathrm{E}$ & $\mathrm{O}$ & $\mathrm{E}$ & $\mathrm{O}$ & $\mathrm{E}$ & & & & & & & \\
\hline AMWS & 22 & 20.0 & 20 & 2.0 & 2 & 0.0 & 0 & 0.955 & 0.045 & 1.09 & 0.086 & 0.086 & 0 & 0 \\
\hline AKS & 46 & 31.4 & 31 & 13.2 & 14 & 1.4 & 1 & 0.826 & 0.174 & 1.40 & 0.287 & 0.287 & 0 & 0.32 \\
\hline AFS & 33 & 22.9 & 22 & 9.2 & 11 & 0.9 & 0 & 0.833 & 0.167 & 1.39 & 0.278 & 0.278 & 0 & 0.48 \\
\hline $\mathrm{AFS} \times \mathrm{T}$ & 40 & 36.0 & 36 & 4.0 & 4 & 0.0 & 0 & 0.950 & 0.050 & 1.10 & 0.095 & 0.095 & 0 & 0 \\
\hline
\end{tabular}


Table 4. Genetic distance indices between gene pools of sheep of Ukrainian selection

\begin{tabular}{lcc|c}
\hline \multicolumn{1}{c}{ Gene pool } & AKS & AMWS & AFS \\
\hline AMWS & 0.129 & - & - \\
AFS & 0.019 & 0.122 & - \\
AFS $\times \mathrm{T}$ & 0.127 & 0.005 & 0.117
\end{tabular}

$(d=0.005)$. The difference between the other pairs of gene pools was much higher and is almost at the same level.

In the study of the Booroola gene polymorphism $(\mathrm{FecB})$, two alternatives were identified, + and $\mathrm{B}$. Allele B is characterised by the presence of a point mutation Q249R at position 746, which leads to the replacement of the amino acid Gln by Arg. In individuals with the B/B genotype, fragments 160 and $30 \mathrm{bp}$ in length appear after restriction. In carriers of the $+/+$ genotype, there is no restriction site for such a restriction enzyme, and a non-restriction amplification product of $190 \mathrm{bp}$ is present. Heterozygotes with B/+ genotype have three fragments simultaneously, 30, 160 and 190 bp long. Using the Avall restriction enzyme, in the studied sheep populations, we established only one fragment, $190 \mathrm{bp}$ in length, which corresponds to the wild type homozygous $+/+$ genotype. The absence of mutations of this gene is a characteristic feature of the Ascanian sheep breed.

According to Mph11030, a polymorphism of the bone morphogenetic protein 15 gene (BMP15), one homozygous genotype of the normal wild type $+/+$ was also identified. However, two allelic variants, + and $\mathrm{A}$, can be identified by this gene. Allele A is characterised by the presence of a FecX1 mutation at position 299, which leads to the replacement of the Val amino acid by Asp ( $\mathrm{T}>\mathrm{A})$. In individuals with the $+/+$ genotype, after restriction, two fragments, 152 and 204 bp in length, appear. In the A/A genotype, there was no restriction site for the restriction enzyme Mph1103, and a non-restriction amplification product of $356 \mathrm{bp}$ was present. Heterozygotes $\mathrm{A} /+$ are distinguished by the presence of three fragments - 152, 204 and $356 \mathrm{bp}$. In general, the studied populations of sheep of Ukraine of various directions of productivity were characterised by the monomorphic state of the BMP15 gene.

In addition to the Booroola and bone morphogenetic proteins, the locus of the myostatin gene is monomorphic. The amplification product using the restriction enzyme Hae III is $337 \mathrm{bp}$ (homozygote $\mathrm{M} / \mathrm{M}$ ). In $\mathrm{m} / \mathrm{M}$ heterozygotes, a fragment with a length of $337,131,123$ and 83 bp was detected, in $\mathrm{m} / \mathrm{m}$ homozygotes, three: 131, 123 and $83 \mathrm{bp}$. Thus, no mutation was detected in the studied gene pools at the MSTN locus, which determines increase in muscle mass of animals.

It is known that mutations in different parts of the studied genes are associated with the manifestation and development of certain economically useful traits of animals, in particular, meat qualities of sheep. This may explain the in-
Table 5. Live weight of lambs AMWS and AKS of different genotypes by $\mathrm{GH}$ locus at different age periods, $\mathrm{kg}$

\begin{tabular}{l|c|c|c|c}
\hline \multirow{2}{*}{ Genotype } & \multirow{2}{*}{$\mathrm{n}$} & \multicolumn{4}{c}{ Age } \\
\cline { 3 - 5 } & & at birth & 4 months & 6 months \\
\hline \multicolumn{2}{l}{ Ascanian } & Meat-and-Wool breed \\
A/A & 21 & $4.9 \pm 0.2$ & $26.7 \pm 1.0$ & $39.0 \pm 1.0$ \\
A/B & 13 & $4.5 \pm 0.3$ & $23.7 \pm 1.0$ & $34.2 \pm 1.1$ \\
Ascanian Karakul breed & & & \\
A/A & 17 & $4.4+0.3$ & $25.8+0.9$ & $34.4+1.0$ \\
A/B & 5 & $4.0+0.3$ & $22.2+1.2$ & $30.1+1.3$
\end{tabular}

terbreed differences in the proportion of structural genotypes, especially the growth hormone gene.

In all the studied populations, despite differences in productivity, selection is being made for development of meat productivity of animals, primarily through an increase in live weight. This process probably affects the accumulation and maintenance of a high level of homozygote A/A and, accordingly, the A allele of the growth hormone and calpastatin genes, since they are involved in the formation of this trait. For the Ascanian Meat-and-Wool and Ascanian Karakul breeds, it was shown that homozygous A/A young animals with the $G H$ gene aged from birth to six months significantly $(p<0.001)$ exceed the developmental body weight of their heterozygous peers (Table 5).

\section{DISCUSSION}

For the first time, the genetic structure of populations of Ascanian Fine-Fleeced, Ascanian Karakul, Ascanian Meatand-Wool breeds and Ascanian Fine-Fleeced $\times$ Texel crosses of Ukrainian selection was studied. Using the PCR method and restriction analysis, polymorphism of the growth hormone and calpastatin genes was shown, as well as the monomorphic state of the genes of Booroola, myostatin and bone morphogenetic protein. It was shown that only the homozygote A/A (100\%) of the growth hormone polymorphism was present in the Ascanian Fine-Fleeced breed. In the remaining gene pools, this genotype and, accordingly, allele $\mathrm{A}$, received an absolute dominance, respectively, $61.8-95.2 \%$ and $0.808-0.976$. The proportion of heterozygote $\mathrm{A} / \mathrm{B}$ varied in the range of $4.8-38.2 \%$. The comparative studies results of the $G H$ gene sequence for sheep, goats and other animal species will be presented in a separate publication.

For the calpastatin gene, the homozygote M/M (66.7$90.9 \%)$ and allele M (0.826-0.955) also dominate. According to the distribution of variants of polymorphic loci, the gene pools of the Ascanian Meat-and-Wool breed and crossbreeding animals are most similar. All studied populations were in a state of genetic equilibrium according to Hardy-Weinberg equations.

It was also found that sheep with the homozygous A/A growth hormone gene were characterised by increased body weight. 
In recent decades, scientists have been studying the polymorphism of quantitative trait genes in the genetic structure of sheep populations of various origins in most developed countries of the world. Various data have been obtained for particular genes. Results similar to ours were obtained for the $G H$ gene. For example, in nine sheep breeds in India, this gene was represented by two genotypes: $\mathrm{AA}$ and $\mathrm{AB}$ (Kumari et al., 2014). Somewhat different results were found in studies on the CAST gene. Two genotypes were identified in four of six studied breeds in Turkey, and three in two breeds (Avanus, 2015). According to genes that determine the level of sheep fertility, the results of the analysis of the genetic structure of various gene pools differ. The $\mathrm{FecB}$ gene in some breeds is in a monomorphic state, which is consistent with our results (Jamshidi et al., 2013), in others - in a monomorphic state (Guan et al., 2006). The same picture is observed for the BMP15 gene (Polley et al., 2009, Shabir et al., 2012).

Regarding myostatin (MSTN), for the vast majority of breeds this gene is monomorphic (Jamshidi et al., 2014; Dimitrova et al., 2016), which is also consistent with the results obtained by us for the sheep of Ascanian selection. This gene is represented by several alleles only in individual populations (Soufy 2009; Lazar et al., 2016).

Thus, for sheep of various breeds in the different regions of the world, QTL genes polymorphisms different, which, in our opinion, is related both to the direction and level the productivity development, and to the specifics of breeding work.

An important task for further research in the genetics of farm animals for the intensification of breeding processes is the introduction of modern DNA technologies for direct analysis of the individual's genetic information at the level of the so-called "main" regulatory or structural genes. These genes take a direct part not only in the formation of economically useful properties, but, despite the polygenic nature of quantitative traits, contribute a significantly larger part to their manifestation compared to other genes. This approach has already proven itself in genomic selection aimed at increasing the fattening and meat indices of young sheep and the reproductive qualities of animals.

In sheep breeding, genes have also been identified with a high degree of certainty associated with the meat qualities of animals, which is confirmed by our studies using growth hormone as an example. Therefore, the concept of further development of research in the field of the use of molecular genetic markers in sheep breeding provides for a gradual transition to the widespread use of modern technologies for directly determining the features of DNA genetic polymorphism in order to develop new, effective methods for assessing genotypes and increasing the level of breeding work. It is envisaged that future research will be aimed at studying the patterns of manifestation of gene associations that provide high animal productivity, evaluation and certification of gene pools of breeds, types and populations of domestic sheep. In addition, the purpose of these studies is the conservation, development and rational use of existing genetic resources, conducting system-monitoring studies of the genetic parameters of the leading pedigree sheep herds in connection with temporary and spatial differentiation, as well as under the influence of various environmental factors.

In addition, despite the use of classical selection based on phenotype selection of individuals today as the only methods, nevertheless, selection pressure has been enough to change the genetic structure of a population at certain loci, which has the most pronounced effect in the manifestation of individual quantitative characters. The possibility of "masking" an undesirable allele in a heterozygous state in the absence of using individual genotype estimation leads to the preservation of different allelic locus variants in a particular population. At the same time, a change in the frequency ratio of alleles can also occur as a result of genetic hitchhiking - a change in the frequency of a neutral allele in a series of generations linked to an associated desirable allele that is associated with a useful trait due to the effect of artificial selection (Hedrick, 2003; Smith et al., 2006). Perhaps it is these factors that explain the presence of certain differences between the gene pools of sheep of different directions of productivity.

\section{REFERENCES}

Ahlawat, A. R., Gajbhiye, P. U., Prince, L. L. L., Meena, A. S., Dongre, V. B., Gajjar, S. G. (2014). Genetic polymorphisms in growth hormone gene in Patanwadi, Marwari and Dumba breeds of sheep. Ind. J. Animal Sci., 84 (9), 1021-1022.

Avanus, K. (2015). Genetic variability of GAST gene in native sheep breeds of Turkey. Kafkas Univ. Vet. Fak. Derg., 21 (6), 789-794.

Davis, G. H., Galloway, S. M., Ross, I. K., Gregan, S. M., Ward, J., Nimbkar, B. V., Ghalsasi, P. M., Nimbkar, C., Gray, G. D., Subandriyo, Inounu, I., Tiesnamurti, B., Martyniuk, E., Eythorsdottir, E., Mulsant, Ph., Lecerf, F., Hanrahan, J. P., Bradford, G. E., Wilson, T. (2002). DNA tests in prolific sheep from eight countries provide new evidence on origin of the Booroola (FecB) mutation. Biol. Reprod., 66 (6), 1869-1874.

Dimitrova, I., Bozhilova-Sakova, M., Stancheva, N., Tzonev T. (2016). Molecular analysis of ovine myostatin gene $(M S T N)$ in northeast Bulgarian merino sheep breed using PCR-RFLP. Bulg. J. Agricult. Sci., 22 (2), 1-3.

El-Hanafy. A. A., El-Saadani, M. A. (2009). Fingerprinting of FecB gene in five Egyptian sheep breeds. Biotechnol. Animal Husbandry, 25, 205-212.

Elkorshy, N., Mahrous, K. F., Salem, L. M. (2013). Genetic polymorphism detection in four Genesin Egyptian and Saudi Sheep breeds. World Appl. Sci. J., 27 (1), 33-43.

Galloway, S. M., McNatty, K. P., Cambridge, L. M., Laitinen, M. P. E., Juengel, J. L., Jokiranta, T. S., McLaren, R. J., Luiro, K., Dodds, K. G., Montgomery, G. W., Beattie, A. E., Davis, G. H., Ritvos, O. (2000). Mutations in an oocyte-derived growth factor gene (BMP15) cause increased ovulation rate and infertility in a dosage-sensitive manner. Nat. Genet., 25, 279-283.

Gong, Y. F., Li, X. L., Liu, Z. Z., Jin, X. M., Zhou, R. Y., Li, L. H., Zhang, Q. (2009). SNP detection and haplotype analysis in partial sequence of MSTN gene in sheep. Russ. J. Gen., 45, 1454-1457.

Guan Feng, Liu Shou-Ren, Shi Guo-Qing, Yang Li-Guo (2007). Polymorphism of Fec B genein nine sheep breeds or strains and its effects on litter size, lamb growth and development. Anim. Reprod. Sci., 99, 44-52.

Hedrick, P. W. (2003). Genetics of Populations. Technosphera, Moscow. 592 pp. (in Russian). 
Ibeagha-Awemu, E. M., Kgwatalala, P., Zhao, X. (2008). A critical analysis of production-associated DNA polymorphisms in the genes of cattle, goat, sheep, and pig. Mam. Genome, 19, 591-617.

Jamshidi, R., Kasirian, M . M., Rahimi, G. A. (2013). Application of PCR-RFLP technique to determine Booroola gene polymorphism in the Sangsari sheep breed of Iran. Turk. J. Vet. Anim. Sci., 37, 129-133.

Jamshidi, S., Karani, S., Goudarzi, M. (2014). Study polymorphism myostatin gene in Mehraban's sheep using PCR-RFLP method. Sci. Int. (Lahore), 26 (3), 1129-1135.

Kambadur, R., Sharma, M., Smith, T. P. L., Bass, J. J. (1997). Mutations in myostatin (GDF8) in Double-Muscled Belgian Blue and Piedmontese Cattle. Genome Res., 7, 910-915.

Koohmaraie, M., Killefer, J., Bishop, M. D., Shackelford, S. D., Wheeler, T. L., Arbona, J. R. (1995). Calpastatin-based methods for predicting meat tenderness. In: Expression of Tissue Proteinases and Regulation of Protein Degradation as Related to Meat Quality. Ouali, A., Demeyer, D. I., Smulders, F. J. M. (eds.). ECCEAMST, Utrecht, pp. 395-410.

Kumari, R., Kumar, R., Meena, A. S., Jyotsana, B., Prince, L. L. L., Kumar, S. (2014). Genetic polymorphism of growth hormone gene in native sheep dreeds of India. Ind. J. Small Rumin., 20 (2), 15-18.

Lazar, C., Glas, Al, M., Rotar, M. C., Pistol, G. C., Pelmus, R. S., Ghita, E. (2016). Identification of myostatin gene polymorphism using PCR-RFLP for improving carcass meat evaluation of Teleorman Black Head Lambs. Anim. Sci. Biotechnol., 49 (1), 63-68.

Merkureva, E. K. (1977). The Genetic Basis of the Cattle Breeding [Меркурьева, Е. К. Генетические основы селекции в скотоводстве]. Kolos, Moscow. 240 pp. (in Russian).

Ghaffari, M., Nejati-Javaremi, A., Rahimi, G. (2009). Detection of polymorphism in $B M P R-I B$ gene associated with twining in Shsl Sheep using PCR-RFLP method. Int. J. Agr. Biol., 11 (1), 97-99.

Montgomery, G. W., Crawford, A. M., Penty, J. M., Dodds, K. G., Ede, A. J., Henry, H. M., Pierson, C. A., Lord, E. A., Galloway, S. M., Schmack, A. E., Sise, J. A., Swarbrick, P. A., Hanrahan, V., Buchanan, F. C., Hill, D. F.
(1993). The ovine Booroola fecundity gene $(\mathrm{FecB})$ is linked to markers from a region of human chromosome 4q. Nat. Genet., 4, 410-414.

Nei, M., Chesser, R. K. (1983). Estimationof fixation indices and gene diversities. Ann. Hum. Genet., 47, 253-259.

Ofir, R., Gootwine, E. (1997). Ovine growth hormone gene duplication structural and evolutionary implications. Mammal. Genome, 8, 770-772.

Palmer, B. R., Roberts, N., Kent, M. P. (1997). A candidate gene approach to animal quality traits. Proc. NZ Soc. Anim. Prod., 57, 294-296.

Peakall, R., Smouse, P. (2012). GenAlEx 6.5: genetic analysis in Excel. Population genetic software for teaching and research - an update. Bioinformatics, 28 (19), 2537-2539.

Polley, S., De, S., Batabyal, S., Kaushik, R., Yadav, P., Arora, J. S. , Chattopadhyay, S., Pan, S., Brahma, B., Datta,T. K. Goswami, S. L. (2009). Polymorphism of fecundity genes (BMPR1B, BMP15 and GDF9) in the Indian prolific Black Bengal goat. Small Rumin. Res., 85, 122-129.

Shabir, M., Ganai, T. A. S. (2019). Nucieotide sequencing and DNA polymorphism studies of BMP 15 gene in Corriedale and local Kashmir valley sheep (Ovis aries). Gene, 499, 231-235.

Shahroudi, F. E., Nassiry, M. R., Valizadh, R., Moussavi, A. H., Pour, M. T., Ghiasi, H. (2006). Genetic polymorphism at MTNR1A, CAST and CAPN loci in Iranian Karakul sheep. Iran. J. Biotechnol., 4 (2), 117-122.

Smith, J. M., Haigh, J. (1974). The hitch-hiking effect of a favourable gene. Genet. Res., Republished 2006, 89 (5-6), 391-403.

Soufy, B., Mohamadabadi, M. R., Shojaeian, K., Baghizadeh, A. Ferasaty, S., Askari N., Dayani, O. (2009). Evaluation of myostatin gene polymorphism in Sanjabi sheep by PCR-RFLP method. Anim. Sci. Res. Tabriz Univ., 19, 81-89.

Szkudlarek-Kowalczyk, M., Wiśniewska, E., Mroczkowski, S. (2011) Polymorphisms of calpastatin gene in sheep. J. Centr. Eur. Agricult., 12 (3), 425-432.

Wallis, M., Lioupis, A., Wallis, O. C. (1998). Duplicate growth hormone genes in sheep and goat. J. Mol. Endocrinol., 2, 1-5.

Received 14 January 2020

Accepted in the final form 12 May 2020

\section{QTL GĒNI UKRAINAS SELEKCIJAS AITU POPULĀCIJĀS}

Vairākām Ukrainā izveidoto aitu škirṇu populācijām tika pētīti kvantitatīvo pazīmju gēni (QTL), kas nosaka būtiskas dzīvnieku produktīvās ìpašỉbas. Visās grupās atrasts polimorfisms gēnos, kuri ir atbildīgi par augšanas hormona un kalpastatīna sintēzi. 